\title{
Questioning the Body: From Technology towards a Sense of Body
}

Koshy Tharakan

\begin{abstract}
Many attempts of contemporary philosophers to reduce 'mind' to 'body' notwithstanding, where the 'body' is understood in the Cartesian framework, the continental philosophers in general repeatedly remind us that body has a significance that goes beyond its materiality as a bio-chemical physical substance. In "questioning body," we wish to take up the philosophical underpinnings of the significance of body as a framework or tool to understand 'technology'. By doing so, we are able to see the link between technology and body as more than a fortuitous relation. Relying on the writings of Heidegger, Merleau-Ponty and Ihde, the paper attempts to show how a "sense of body," particularly the notion of "agentive body" as distinguished from the "symbolic body," hermeneutically evolves from the way in which it is entangled in the technological matrix.
\end{abstract}

Key words: Heidegger, Merleau-Ponty, body, technology

\section{Introduction: Technology and Body}

$\mathrm{M}$ any attempts of contemporary philosophers to reduce 'mind' to 'body' notwithstanding, where the 'body' is understood in the Cartesian framework, the continental philosophers in general repeatedly remind us that body has a significance that goes beyond its materiality as a bio-chemical physical substance. In "questioning body," we wish to take up the philosophical underpinnings of the significance of body as a framework or tool to understand 'technology'. In the process, the paper attempts to show how a "sense of body" evolves hermeneutically.

It is otiose to state that technology is the most visible thread by which the modern societies are connected with each other in their economic and other socio-cultural spheres. However, a philosophical take on technology inevitably leads us to probe our own 'body'. The link between 'technology' and 'body' is more obvious than any philosophical arguments that purport to establish the 'truth' of 'individualism' against 'holism' as an ontological statement about society-'society' as a conglomeration of individual 'bodies.' Rather, as Fortunati et al. point out, ." . . [T] he body is increasingly running the risk of becoming an appendix to the machine, despite there being, as Nietzsche 
wrote . . more reason in the body than in our best wisdom."1 Those who apprehend this possibility argue that, technology has become an end in itself rather than a mere means for human ends. As an end in itself, technology has succeeded in "invading the body." Thus, Fortunanti et al. remarks:

The human body is undergoing the same processes today that nature once underwent. In fact, whereas initially technology turned to nature, today it has become very interested in the human body . . . Communication technologies have extended the boundaries of the body, increasing the capacity to transmit information. Technology has progressively grown closer to our bodies, approaching through first clothing, then synthetic clothing fibers, and finally "smart fabrics," wearable computers, and communicative machines embedded ... into the body. ${ }^{2}$ complete!

With the advent of the Cyborg, the technological invasion of body is

\section{Philosophy of Technology: Heidegger's Questioning}

Philosophical reflection on technology seems to be as old as philosophy itself. However, as Ihde remarks, though ." . . there is a vast literature concerning technology, rarely has it been the primary theme of philosophers ... even within the plethora of books concerning the human impact of technology, few are concerned with the nature of technology per se. Either the literature tends to focus upon effects of technology or it may itself be technical literature."’3 Ihde himself provides an illuminating reason for this inexplicable silence on the part of philosophers:

Part of the silence concerning technology comes from within philosophy itself. Philosophy usually conceives of itself more as a type of "conceptual" engineering than as a "material" engineering. Here there is a deeper set of relationships between science and technology as they emerge both in ancient and contemporary thought in philosophy. This symptomatology points to the dominance of a long "Platonistic" tradition with respect to science and technology, a tradition which, with respect

1 Leopoldino Fortunanti, James E. Katz and Raimonda Riccini, introduction to Mediating the Human Body: Technology, Communication and Fashion (Mahwah, New Jersey: Lawrence Erlbaum Associates, 2003), 2.

2 Ibid., 3-5.

${ }^{3}$ Don Ihde, Instrumental Realism: The Interface Between Philosophy of Science and Philosophy of Technology (Bloomington and Indianapolis: Indiana University Press, 1991), 3. 
to science and technology, turns out to be "idealistic." ... a "Platonistic" tradition is one which negatively judges, or at least evaluates, perception and embodiment as lower on the scale of human activity than what is presumed to be a "pure" conceptuality.

As against the "Platonistic" tradition, the "Praxis" tradition acknowledges the primacy of a theory of action that attaches a positive value to "perception" and "embodiment." Ihde reads Heidegger as a pioneer who belonged to the praxis tradition. Heidegger is foremost amongst the twentieth Century philosophers who reflected critically on technology. As some recent philosophers of technology note, for Heidegger the pivotal role of technology in modern society is symptomatic of a "wrongheaded attitude towards Being." For Heidegger, the purpose of philosophy is to concern itself with 'Being'. However, in thinking of 'Being qua Being' or the 'being of beings', its relatedness to man's nature has been already implicated. So an existential analytic of Dasein must proceed from its average everydayness. The world of everyday Dasein, which is closest to it, is the environment. In the environing world, we do not encounter 'mere things' per se. Such things come across to us with regard to our interests. Our dealings in the world and with things in the world are by way of 'concern'. Heidegger calls those entities, which we encounter in concern "equipment" or "tool" (de Zeug). Equipment always belongs to the horizon of a totality of equipments, their interrelatedness. There is not just a thing as 'equipment'; rather there always exists a totality of equipments. What an item of equipment depends on the way it is related to or assimilated into the total equipmental context. In other words, an object derives its essence from its functional role as well as its actual existence. Heidegger terms the entities encountered as equipments as 'ready-to-hand' (Zuhanden) as against those encountered in theoretical cognition, 'the presentat-hand' (Vorbanden). For Heidegger, the level of 'Zubandenheit is basic and 'Vorbandenheit' is a second level abstraction. These are not two distinct types of ontic entities; rather it refers to a distinction in Dasein's way of viewing the entities. When Dasein 'views' with circumspection the entities show themselves as ready-to-hand equipments. When Dasein adopts an attitude of merely observing, the very same entities appear as merely present at hand. ${ }^{6}$

In advocating a "praxis-perception model" for both philosophy of science and technology, Ihde emphasizes the significance of Heidegger's "tool analysis" for philosophy of technology. According to Ihde, the decisive shift that Heidegger brought to our view may be termed as "materialist." The "materialist" shift that Heidegger inaugurated in his Being and Time, has

${ }^{4}$ Ibid., 5.

5 Maarten Franssen et al., "Philosophy of Technology," in Stanford Encylopedia of Philosophy < http://plato.stanford.edu/entries/technology/\#MetIssStaChaArt>, 5 June 2010.

${ }^{6}$ Martin Heidegger, Being and Time, trans. by John Macquarrie and E. Robinson (New York: Harper and Row, 1962), 95-102. 
"inverted the standard view of the science-technology relation to that of technology-science." ${ }^{, 7}$ It was a long held view that technology is mere "applied science." The standard view thus accords primacy to science construed in the "Platonistic" tradition of "pure conceptuality." Heidegger's famous example of hammer serves our purpose here. As the "tool" analysis shows, a hammer is not first known as an "object" having certain weight such that it qualifies as a heavy object with such and such a shape or extension. Rather, we encounter hammer as an "embodiment which extends some human activity into its pragmatic context within an immediate environment." "While we use the hammer, its "cognitive properties" are secondary and as an "object," the hammer "withdraws" itself. As Heidegger says:

The peculiarity of what is proximally ready-to-hand is that, in its readiness-to-hand, it must, as it were, withdraw $\ldots$. . in order to be ready-to-hand quite authentically. That with which our everyday dealings proximally dwell is not the tools themselves... On the contrary, that with which we concern ourselves primarily is the work.

While using the hammer, say to drive a nail, if we cognitively attend to the hammer, then we make wrong nailing. In use, the tools possess a "dynamic" being of their own and they cease to be objects "known." Again, the "dynamic being" of the tool is contextual. The tool belongs to a "toolcontext." In the case of hammer, it would be the nails, the wood, etc. In fact, the tool context leads to an entire environment and implicitly with it a "world." Heidegger writes:

Any work with which one concerns oneself is ready-tohand not only in the domestic world of the workshop but also in the public world. Along with the public world, the environing Nature . . . is discovered and is accessible to everyone. In roads, streets, bridges, buildings, our concern discovers Nature as having some definite direction. A covered railway platform takes account of bad weather; an installation for public lighting takes account of the darkness ... When we make use of the clock-equipment, which is proximally and inconspicuously ready-to-hand, the environing Nature is ready-to-hand along with it. Our concernful absorption in whatever work-world lies closest to us, has a function of discovering; and it is essential to this function that, depending upon the way in which we are absorbed, those

\footnotetext{
${ }^{7}$ Ihde, op cit., 48.

8 Ibid., 52.

${ }^{9}$ Heidegger, op cit., 99.
} 
entities within-the-world which are brought along . . . in the work and with it . . . remain discoverable in varying degrees of explicitness and with a varying circumspective penetration. ${ }^{10}$

Thus, the ready-to-handiness of the tool opens up a wider environment and finally leads to Dasein as "for the sake of whom" the "inorder-to" structure of the tool points. As Ihde says, this "praxical perceptual" dimension of human experience is available in some way or other to all human communities. Such experience occurs both "without" science as well as "within" science. This implies that "technology" is not to be taken as "applied science," rather "technology is broader than an explicit science."11

"The Heideggerian inversion," effected by the "tool" analysis makes a fundamental move in ontology as it makes "readiness-to-hand" as the basic ontological category by which entities are defined as they are "in themselves." It is only when the "tool-hood" is broken that the "readiness-to-hand" turns into a "present-at-hand" entity amenable to a sort of "theoretical" knowledge. Thus, as Ihde observes:

This derivation of the occasion of "knowledge" makes the totality of the objects of knowledge not only derivative but special cases of human concern and activity. "Observer" consciousness is a particular development of actional, prior concerns. Thus, underneath the presumed disinterestedness of observation lies the engagement of praxis. ${ }^{12}$

In other words, technological praxis is not an application of science; rather science is now seen as "the tool of technology." 13 This inversion is explicitly stated in Heidegger's later reflection on technology:

It is said that modern technology is something incomparably different from all earlier technologies because it is based on modern physics as an exact science. Meanwhile we have come to understand more clearly that the reverse holds true as well: modern physics, as experimental, is dependent upon technical apparatus and upon progress in the building of apparatus. ${ }^{14}$

\footnotetext{
10 Ibid., 100.

${ }^{11}$ Ihde, op cit., 53.

12 Ibid., 54-55.

13 Ibid., 55.

14 Martin Heidegger, "The Question Concerning Technology," in Martin Heidegger.
} Basic Writings, ed. by David Farrell Krell (London: Routledge and Kegan Paul, 1978), 295-96. 
However, as Heidegger himself points out, the above statement only makes certain "facts" about technology. What is more significant is to grasp the "essence" of technology. Thus, Heidegger asks, "What is the essence of technology?" On first count, technology shows up as a "means to an end" and as a "human activity." This definition of technology, Heidegger calls the instrumental and anthropological definition. The instrumental-anthropological definition, though is correct does not reveal the essence of technology as Heidegger says, "the merely correct is not yet the true." Thus, he further asks, "What is the instrumental itself? Within what do such things as means and end belong?" Heidegger's questioning traces instrumentality back to "fourfold causality." Further interrogation reveals that the four causes-the formal, the material, the efficient and the final_ " "are the ways, all belonging at once to each other, of being responsible for something else." 15 The "four ways of being responsible" together bring forth something into appearance. According to Heidegger, even the coming of something from out of itself, physis, is also a bringing forth:

Not only handcraft manufacture, not only artistic and poetical bringing into appearance and concrete imagery, is a bringing-forth, poiesis. Physis also, the arising of something from out of itself, is a bringing-forth, poiesis. ${ }^{16}$

The growing things of nature as well as the products of arts and crafts thus make their presence through bringing-forth. But, bringing-forth happens only if "something concealed comes into unconcealment." The "revealing" of the concealed is "aletheia," the Greek term that got translated as "truth." Thus, Heidegger's search for the essence of technology thus shows that technology is no mere means; rather technology is a way of revealing. Technology as a mode of revealing characterizes not only earlier technologies of handcrafts. Even modern technology is also a mode of revealing, albeit a different one. As Heidegger says:

. . . the revealing that holds sway throughout modern technology does not unfold into a bringing-forth in the sense of poiesis. The revealing that rules in modern technology is a challenging . . . in that the energy concealed in nature is unlocked, what is unlocked is transformed, what is transformed is stored up, what is stored up is, in turn, distributed and what is distributed is switched about ever anew. Unlocking, transforming, storing, distributing, and switching about are ways of revealing. $^{17}$

\footnotetext{
15 Ibid., 290.

16 Ibid., 293.

17 Ibid., 296-98.
} 
The revealing, however, does not come to a standstill. The manifold ways of revealing and setting upon of the challenging-forth is gathered together under the rubric of "Ge-stell" or "Enframing." However, Heidegger's revealing of the essence of technology as "enframing" renders technology aporetic. As Belu and Feenberg point out:

... enframing is not simply a widespread "problem" we could solve with appropriate remedies, but the underlying structure of being in our time. It is ontological rather than ontic ... However, the universality of enframing would seem to block knowledge of it. The enframed subject should not be able to understand or to have a sense of her own enframing. ${ }^{18}$

As seen above, either Heidegger's characterization of the essence of technology as enframing is only a partial enframing and to that extent, the essence of technology is compromised or it is total enframing in which case human beings too are enframed and to that extent no theory of enframing is conceivable. $^{19}$ The aporetic understanding of technology emanating from Heidegger's questioning may be rendered less aporetic if we begin our questioning with body rather than technology per se. Merleau-Ponty, through his ontology of flesh, offers us precisely such a possibility.

\section{Philosophy of Body: Merleau-Ponty's Ontology of Flesh}

According to Merleau-Ponty, our relation to the world is not one between the thinker and his object of thought. The world we actually perceive is not the 'objective' world, rather it is the world of our everyday life, the one in which we 'live-through'. In the 'lived world' one deals with objects that are 'situated' in relation to specific human actions. In other words, it is the human body as subject of action which determinates the objects as situated in its field of action. Merleau-Ponty writes:

Our bodily experience of movement is not a particular case of knowledge; it provides us with a way of access to the world and the object, with a 'praktognosia', which has to be recognized as original and perhaps as primary. My body has its world, or understands its world, without

18 Dana S. Belu and Andrew Feenberg: "Heidegger's Aporetic Ontology of Technology," in Inquiry, 53 (No.1, 2010), 2.

${ }_{19}$ Ibid., 8. 
having to make use of my 'symbolic' or 'objectifying function. $^{20}$

Thus, the subject, by its very nature as embodied consciousness, right from its beginning is oriented towards the world. One's body and the world are not to be understood as objects coordinated together by a functional relationship that objective thought establishes. The relation between my body and the world rather should be understood in terms of a real implication. Merleau-Ponty understands that subject's interactions with the world are not primarily through the intellectual powers but through habits. When the body inhabits the space, it is done through habits and body has habits through inhabiting space. Habits and inhabiting are mutually implicatory. ${ }^{21}$ According to him, the habit's contributions to inhabiting is sedimented generalized possibilities for inhabiting and inhabiting's contribution is pre-reflectively knowing one's way around enabling habitual actions.

As Merleau-Ponty says, the expressive spatiality is the projection of body-consciousness to another object in space. He gives the example of a typewriter's keyboard as an instance of specific spatiality. While one types, one's body spatiality gets merged with that of the keyboard's spatiality. The "subject who learns to type incorporates the key-bank space into his bodily space." 22 Another example that Merleau-Ponty gives is a blind man's cane:

The blind man's stick has ceased to be an object for him, and is no longer perceived for itself; its point has become an area of sensitivity, extending the scope and active radius of touch, and providing a parallel to sight. In the exploration of things, the length of the stick does not enter expressly as a middle term: the blind man is rather aware of it through the position of objects than the position of objects through it. The position of things is immediately given through the extent of the reach which carries him to it, which comprises besides the arm's own reach the stick's range of action ... The points in space do not stand out as objective positions in relation to the objective position occupied by our body; they mark, in our vicinity, the varying range of our aims and our gestures. To get used to a hat, a car or a stick is to be transplanted into them, or conversely, to incorporate them into the bulk of our own body. ${ }^{23}$

20 Maurice Merleau-Ponty, Phenomenology of Perception, trans. by Colin Smith (London: Routledge and Kegan Paul, 1962), 140-141.

${ }^{21} \mathrm{Ibid}$, . 304-305.

22 Ibid., 145.

${ }^{23}$ Ibid., 143. 
The possibility of thus extending one's body space to other objects through expressive spatiality, suggests a new way to understand technology. As Ihde points out, these are examples of "embodiment relations." Such relation, Ihde notes, "are existential (bodily-sensory), but they implicate how we utilize technologies and how such use transforms what it is we experience through such technologies." In the Visible and the Invisible, Merleau-Ponty provides a new ontology by introducing the notion of 'flesh'. The flesh is a primal 'element' and both the subject and the world are born out of it. It is neither a mind nor a material substance. The distinguishing characteristic of flesh is its 'intertwining' relations. Using the example of one hand touching the other hand and being touched in turn, Merleau-Ponty says that the body can play the role of both the perceiver and the perceived. As he points out, there is an identity-in-difference when the two hands touch. The two hands are never, with regard to one another, "touched and touching at the same time." The notion of "identity-in-difference" is fundamental to Merleau-Ponty's ontological description of the visible. It is not only applicable to the experience of touch, but is relevant in the way in which the body is related to the world. Both my body as well as the world is flesh. The flesh of my body perceives the world as flesh. This new ontology negates the dualistic ontology that institutes a separation between my mind and body and between my body and the world.

\section{Conclusion: Body/Technology}

Dreyfus attempts to free the aporetic nature of Heideggerian ontology of technology by invoking marginal practices as the source of resistance to the enframing. Thus, Dreyfus writes:

... although a technological understanding of being is our destiny it is not our fate. That is, although our understanding of things and ourselves as resources to be ordered, enhanced and used efficiently has been building up since Plato, we are not stuck with that understanding. Although the technological understanding of being governs the way things have to show up for us, we can be open to a transformation of our current cultural learning. ${ }^{24}$

As Belu and Feenberg show, the textual inspiration for suggesting marginal practices as offering resistance to enframing comes from Heidegger's remark in "Question Concerning Technology" that the saving power is to be

24 Hubert Dreyfus, "Heidegger on the Connection Between Nihilism, Art, Technology and Politics," in The Cambridge Companion to Heidegger, ed. by Guignon C.B. (London: Cambridge University Press, 1998), 307. Quoted in Dana S. Belu and Andrew Feenberg, op cit., 10. 
found "[h]ere and now and in little things." ${ }^{, 25}$ However, this option seems to be doubtful as such a practice as Belu and Feenberg say remains an ontic solution whereas enframing is ontological. This perhaps necessitates a new ontology of technology and body. The ontology of flesh as well as Merleau-Ponty's characterization of the "mutual implication" of 'habit and 'inhabiting', I suggest mitigate the aporia of Heidegger's notion of "enframing" as the essence of technology. Perhaps, what is aporetic is not the ontology of technology, but the body as flesh.

To flush out the aporia of body as flesh, we may focus on the two conceptions of body available in anthropological discourse: body as "symbol" and body as the "agent." Mary Douglas was one of the pioneers who articulated the notion of body as symbol. According to Douglas, the social situation is "replicated" symbolically by our body. The notion of "symbolic body" renders the body to be "viewed metaphorically as a text that can be "read" as a symbol or signifier of the social world that it inhabits." ${ }^{, 26}$ MerleauPonty provides a succinct account of the "agentic body" as well as how body extends itself through technology, when he says that:

The body is our general medium for having a world. Sometimes it is restricted to the actions necessary for the conservation of life, and accordingly it posits around us a biological world; at other times, elaborating upon these primary actions and moving from their literal to a figurative meaning, it manifests through them a core of new significance: this is true of motor habits such as dancing. Sometimes, finally, the meaning aimed at cannot be achieved by the body's natural means; it must then build itself an instrument, and it projects thereby around itself a cultural world. At all levels it performs the same function which is to endow the instantaneous expressions of spontaneity . . .${ }^{27}$ (italics mine)

Following Merleau-Ponty, we may thus say that technology is an "expression" of the body, an extension of the body and body is the "medium" of a technological world. This reciprocal "envelopment" of body and technology would make sense if we construe the body that extends itself not as a Cartesian res extensa but as an "embodied mind" manifested by ontology of "flesh." In other words, technology may be now understood as extension of the "agentic body." Such an understanding of technology as an extension of agentic body not only alleviates the Heideggerian aporia to a great extent but also projects hermeneutically the sense of the body as agentic in contrast to the

${ }^{25}$ Heidegger, "Question Concerning Technology,” 315.

${ }^{26}$ Erica Reischer and Kathryn S. Koo: "The Body Beautiful: Symbolism and Agency in the Social World," in Annual Review of Anthropology, 33 (2004), 300.

${ }^{27}$ Merleau-Ponty, op cit., 146. 
symbolic sense of the body. The apprehension expressed at the outset, of the body being invaded by technology would be true of the "symbolic body," whereas for the "agentic body" technology would be a tool to "extend" agency. Thus, even while technology invades the symbolic body, there remains an element of agentic body beyond technology through the power of its agency, an agency that is capable of the "saving power" that Heidegger had alluded to.

Department of Philosopby, Goa University, India

\section{References}

Belu, Dana S. and Feenberg, Andrew, "Heidegger's Aporetic Ontology of Technology," in Inquiry, 53:1 (2010).

Fortunanti, Leopoldino, Katz , James E and Riccini, Raimonda ed., Mediating the Human Body: Technology, Communication and Fashion (Mahwah, New Jersey: Lawrence Erlbaum Associates, 2003).

Franssen, Maarten, Lokhorst, Gert-Jan and Poel, Ibo van de, "Philosophy of Technology," in The Stanford Encyclopedia of Philosopby (Spring 2010 Edition), Edward N. Zalta (ed.), URL = $<$ http://plato.stanford.edu/archives/spr2010/entries/technology/>.

Guignon, C.B. ed., The Cambridge Companion to Heidegger (London: Cambridge University Press, 1998).

Heidegger, Martin, Being and Time, trans. by John Macquarrie and E. Robinson (New York: Harper and Row, 1962).

Ihde, Don, Instrumental Realism: The Interface Between Pbilosopby of Science and Philosophy of Technology (Bloomington and Indianapolis: Indiana University Press, 1991).

, Technics and Praxis: A Pbilosophy of Technology (Dordrecht: D. Reidel Publishing Co., 1979).

Krell, David Farrell (ed.), Martin Heidegger: Basic Writings (London: Routledge and Kegan Paul, 1978).

Merleau-Ponty, Maurice, Phenomenology of Perception, trans. by Colin Smith (London: Routledge and Kegan Paul, 1962).

Reischer, Erica and Koo, Kathryn S., "The Body Beautiful: Symbolism and Agency in the Social World," in Annual Review of Anthropology, 33 (2004). 